University of New Orleans

ScholarWorks@UNO

$1-1994$

\title{
The Unique Role of Logic in the Development of Heidegger's Dialogue with Kant
}

Frank Schalow

University of New Orleans, fschalow@uno.edu

Follow this and additional works at: https://scholarworks.uno.edu/phil_facpubs

Part of the Philosophy Commons

\section{Recommended Citation}

Schalow, Frank. "The Unique Role of Logic in the Development of Heidegger's Dialogue with Kant," Journal of the History of Philosophy, 32/1 (Jan. 1994): 103-125.

This Article is brought to you for free and open access by the Department of History and Philosophy at ScholarWorks@UNO. It has been accepted for inclusion in Philosophy Faculty Publications by an authorized administrator of ScholarWorks@UNO. For more information, please contact scholarworks@uno.edu. 


\title{
The Unique Role of Logic in the Development of Heidegger's Dialogue with Kant
}

\author{
FRANK SCHALOW
}

IN KANT AND THE PROBLEM OF METAPHYSICS, Heidegger maintains that the crux of his radical reinterpretation of transcendental philosophy centers on revamping Kant's most decisive innovation, the Copernican Revolution in philosophy. According to Heidegger, Kant's attempt to shift the focus of metaphysics from a concern for the nature of the object to the finite conditions that make possible our relation to it amounts to showing that any comportment toward beings presupposes the preunderstanding of being. ${ }^{1}$ It is precisely the simplicity of Heidegger's first step in the Kant book that I wish to call into question. Specifically, I intend to argue that Heidegger does not merely substitute his own emphasis on the question of being for Kant's critical endeavor to circumscribe the boundaries of reason. Rather, I will show that Heidegger approaches transcendental philosophy as providing a further inroad into the attempt to unfold the roots of our basic patterns of thought, and thereby as suggesting a topography to chart the deeper unity of logic and ontology which had become noticeably separated in modern philosophy.

Heidegger's attempt in the Kant book to uncover the origin of truth in Dasein's finite transcendence can be appreciated only by showing its prefigurement in his earlier lectures, which begin to uproot the priority of the assertion as the definitive locus of truth. The breakthrough that Heidegger accomplishes in the Kant book is not an isolated event; it instead presupposes

' Heidegger, Kant und das Problem der Melaphysik, Gesamtausgabe 3 (Frankfurt am Main: Vittorio KJostermann, 195 1), 13, 15-16; Kant and the Problem of Metaphysics, tr. Richard Taft (Bloomington: Indiana University Press, 1990), 8, 10. Hereafter, all references to the Gesamtausgabe will include the abbreviation GA followed by the volume number, German pagination, and the corresponding page number in the English translation (i.e., tr.), where applicable. 
a move in which he redefines knowledge in terms of our comportment toward beings, and locates the site for determining meaning within the referential structure of the world rather than more narrowly within judgment. The overturning of the preeminence of the "as" of assertion by the "hermeneutical as" provides the key to the transformation of logic which forms the cornerstone of the Kant book. From the beginning of his career Heidegger had been familiar with Kant's writings, and had been influenced by the dominant school of German philosophy at that time, neo-Kantianism.: But it was not until he abruptly changed the outline of his lecture course Logik: Die Frage nach der Wahrheit, at the close of the winter semester of $19^{2} 5$, that he seized upon the brilliance of Kant's insight into the temporal formation of the categories through schematism.3

The direction taken by these $1925^{-26}$ lectures becomes important by first marking the differences between Heidegger's own task and Kant's. It is the gradual dissolution of these barriers which makes the emerging parallels-the key themes of finitude, temporality, and transcendence-prove particularly compelling. Because of its detailed treatment of these motifs, the Kant book has provided the paradigm for understanding Heidegger's interpretation of transcendental philosophy. Few scholars have paused to consider why Heidegger should turn suddenly to Kant's doctrine of schematism as providing an entirely new angle from which to formulate the question of being. To be sure, we could continue to affirm the centrality of this doctrine due to its temporal focus and thereby assume the plausibility of Heidegger's decision to vault Kant into the forefront of his own ontological inquiry. Yet it might be more rewarding instead to distinguish the gulf initially separating the two thinkers, the very overcoming of which creates the dialogical space in which the provocative analyses comprising the Kant book already move.4 Specifically, I wish to ask how Heidegger can overcome the limited applicability of schematism for determining the orderliness of natural events, and redefine more broadly its temporal

-Cf. Heidegger's discussion of the neo-Kantian Windelband's view of judgment in Zur Bestimmung der Philosophie, GA ${ }_{5}^{6 / 57}: 15$ Iff. Much of Heidegger's early development centers around his exchange with the Marburg school of neo-Kantians, as seen most prominently in the figure of Cohen, as well as the influence exerted by his teacher, Rickert. Much of Heidegger's effort to formulate his concept of logic springs from his concern with the neo-Kantian explanation of the formation of categories, although he was later to transpose it as an emphasis on existentials rather than categories of the present-at-hand.

3 Heidegger, Logik: Die Frage nach der Wahtheit, GA 21. Cf. Walter Biemel's allusion in the Nachwort to the Logik's providing the germ for the Kant book. Also see Theodore Kisiel, "Why the First Draft of Being and Time Was Never Published," Joumal of the British Society for Phenomenology 20 (January 1989): 18-20.

Cf. Frank Schalow, The Renewal of the Heidegger-Kant Dialogue: Action, Thought and Responsibility (Albany, N.Y.: SUNY Press, 1992). 
character in terms of human understanding (Verstehen) in its interpreted, historical concreteness. Such a development, which may be said to have been pioneered by Dilthey toward the end of the nineteenth century, 5 paves the way for Heidegger to address temporality as defining the lived character of human existence, and thereby to develop a hermeneutics of that experience that seeks preliminary guidance from the recesses of Dasein's preontological understanding of being. ${ }^{6}$ Only by showing how the cognitive formation of the categories through schematism arises from a temporality that is first experienced prethematically in the lived guise of Verstehen can Heidegger develop a common vocabulary to initiate a dialogue with Kant. 7 My aim here is to demonstrate how this implicit need to develop such a vocabulary leads Heidegger in his 1925-26 lecture course into a rather abrupt encounter with transcendental philosophy, and that it is precisely this development which is presupposed as the dramatic breakthrough witnessed in the Kant book.

My discussion proceeds in three stages. First, I will consider the move which defines Heidegger's attempt to recover a deeper sense of logic and determines how Kant's treatment of such matters as judgment, the categories, and truth becomes essential to this transition. Second, I will establish how the gradual retraction of the barriers separating Heidegger's thought from Kant's allows logic to become a passageway to ontology. Third, I will show how the method which Heidegger later practiced in the lecture course comprising The Basic Problems of Phenomenology - the method of reduction, construction, and destruction-indicates stages in assembling the horizon for the radical reinterpretation of transcendental philosophy consummated in the Kant book. ${ }^{8}$

\section{THE BROADER DETERMINATION OF THE “TRANSCENDENTAL"}

With the recent acknowledgment that the direction of Heidegger's questioning was already determined before Being and Time, a perennial concern requires attention once again: How truly "Kantian" is that work?9 This query resounds with many connotations as to the "transcendental" character of that investigation into the conditions for the possibility of understanding being; indeed,

\footnotetext{
5 Kisiel, "Why the First Draft," $12-14$.

${ }^{6} \mathrm{Cf}$. Rudolf A. Makkreel, "The Genesis of Heidegger's Phenomenological Hermeneutics and the Rediscovered 'Aristotle Introduction' of 1922," Man and World 29 (1990): 906-907, 311, , 16.

${ }^{7}$ Ibid, 916 . Also see GA $56 / 57$ : $129 \mathrm{ff}$. Of special importance are Heidegger's allusions to Lask and Dilthey, as prefiguring the concern for the structural formation of meaning, or its genesis, in relation to history and culture.

'Heidegger, Die Grundprobleme der Phänomenologie, GA 24: 25-91; The Basic Problems of Phenomenology, tr. Albert Hofstadter (Bloomington: Indiana University Press, 1982), 19-29.

${ }^{9}$ Cf. Charles M. Sherover, "Heidegger's Use of Kant in Being and Time," in Kant and Phenomenology, ed. Joseph Kockelmans and Thomas Seebohm (Washington D.C.: University Press of America, 1986).
} 
some scholars believe that the purity of Heidegger's earlier phenomenology may have been corrupted by his subsequent allegiance to transcendental philosophy..$^{\circ}$ In momentarily waiving any evaluations, we need to ask how exclusively Kantian is Heidegger's employment of the "transcendental"; may it not be the case that he seeks a broader determination of it which resonates as much with Greek philosophy beginning with Aristotle as with German idealism?

In proposing a new point of departure for ontology, Heidegger identifies that task as one which is scientific." For him, science is not to be taken in a narrowly modern way, but more broadly as referring to an understanding that recovers on a more universal plane the meanings already housed within the immediacy of factical experience. Ontology then seeks to delimit this understanding; by tracing its own evolution from a pre-ontological grasp of being, ontological inquiry seeks a primordial form of articulation or discourse, a logos which gathers together all manifold senses of "being" by nurturing them within the folds of a deeper disclosure. Taking Brentano's reading of Aristotle as his point of departure, Heidegger views the categories less as linguistic structures and more as delimiting basic ways in which beings reveal themselves. " His approach proves unique by showing how time yields the avenue for such revealing or disclosure and thereby assumes a "constitutive" role in interweaving the various senses of being. Temporality (Temporalität) provides the inclusive pattern, what he calls the "upon which" (woraufhin), for being's comprehension and subsequent expression in discourse.

Seen in this light, the transcendental entails a concern not simply for defining being, but rather for what facilitates any move towards its determination, or brings it forth for disclosure; there is an implicit sense of going beyond, or "transcendence," a phenomenon which Heidegger will frequently describe in its existential demeanor as defining Dasein or as comprising beingin-the-world as such. ${ }^{13}$ Appropriately, at the close of the second introduction to Being and Time, Heidegger describes "phenomenological truth" (the dis-

10 John van Buren, "The Young Heidegger and Phenomenology," Man and World 23 (1990): 261-63; and "The Young Heidegger: Rumor of a Hidden King (1919-1926)," Philosophy Today 33 (Spring 1989): 104. Also see Theodore Kisiel, "The Missing Link in the Early Heidegger's Thought," in Hermeneutic Phenomenology, ed. Joseph Kockelmans (Washington D.C.: University Press of America, 1988), $15 \mathrm{ff}$.

"GA 24: 15 ; tr. 11.

"For Heidegger's earliest treatment of the problem of predication, see Frühe Schriften, GA 1: $121 \mathrm{ff}$. As far back as his earliest investigation, Neuere Forschungen über Logik (1912), Heidegger had envisioned the problem of discerning the categorial formation of meaning as developed by Emil Lask and others of the neo-Kantian school, as well as the implications that a reinterpretation of Kant's transcendental philosophy held for understanding logic more primordially (e.g., GA 1: 32ff.).

13 Heidegger, Vom Wesen des Grundes, in Wegmarken, GA 9; The Essence of Reason, tr. Terrence Malick (Evanston: Northwestern University Press, 1969), 41. 
closedness of being) as "veritas transcendentalis," with the prefatory remark that "every disclosure of being as transcendens is transcendental knowledge." 14

Heidegger's allusion to the transcendental as what lies "higher" entails his own radical way of distinguishing being from beings. Yet even here there is already a faint hint of adopting a traditional problematic, of recalling in a new way the medieval connection between being and truth, as suggested by his employment of the Latin term veritas. What distinguishes Heidegger's approach, however, is that he begins by conceding an initial perplexity about the meaning of being, and hence begins from a recognition that what is concealed in the traditional ontological formulation is also essential to being's disclosure. For example, the attempt to extend the inquiry toward what is most universal hinges on confronting the opposite problem that 'being' can just as easily be construed as the vaguest, most indeterminate concept. ${ }^{15}$ To mark the juncture where his own inquiry turns in a direction opposite to the tradition, Heidegger states, in the same passage as quoted above: "Being, as the basic theme of philosophy, is no class or genus of beings; yet it pertains to every being. Its 'universality' is to be sought higher up." 16

Heidegger's rendering of his approach to the study of being in the second introduction to his magnum opus remains somewhat dense because it assumes that ontology encapsulates the problems inherited from logic. Or more precisely, he begins from a questioning which already seeks to break down and reassemble the traditional concerns of language and truth, whose consummation lies far ahead of even those basic clues that have been gathered from the earlier lectures. This is an important point if we are to weigh seriously the criticism advanced by Rudolf Makkreel, for one, in maintaining that in his interpretation of Kant Heidegger seeks a too close alignment between the temporality defining human existence as care and that found in schematism and imagination within the domain of knowing. ${ }^{17}$

The gradual ascent of Heidegger's inquiry toward an apex, toward reclaiming the "transcendental," entails not only redefining the nature of traditional logic, but also relocating its most seminal concerns within the question of being. By providing this new landscape for ontology, Heidegger is able to 1 ) determine exactly how a concern for logic remains despite the overthrow of

"4 Heidegger, Sein und Zeit, GA 2: 51; Being and Time, tr. John Macquarrie and Edward Robinson (New York: Harper \& Row, 1962), 62.

15 GA 2: 4-5; tr. 22-23.

${ }^{16} \mathrm{GA} 2: 51 ;$ tr. 62.

17 Rudolf A. Makkreel, Imagination and Interpretation in Kant (Chicago: The University of Chicago Press, 1990), 20-25. In another context, Makkreel suggests that Heidegger expanded the Kantian notion of the transcendental beyond its closer alignment with the constitution of knowledge via pure apperception. See "The Genesis of Heidegger's Phenomenological Hermeneutics," 316. 
metaphysics and 2) establish the commonality between apparently diverse approaches to such important topics as (the status of) the categories in such thinkers as Aristotle and Kant. ${ }^{18}$ Insofar as his questioning spans an interval joining these two seminal figures, Heidegger retracts the barriers which separate his own thought from Kant's and thereby sets the stage for showing how the latter's grasp of the transcendental prefigures his own rendering of transcendence as the site of truth as disclosedness.

For Heidegger, the transcendental does not simply involve a modern concern for the possibility of knowledge, or the emergence of an object in conformity with the constitution of the knowing subject, as suggested in Kant's statement of the Copernican Revolution. Even in his $19^{2} 5$ analysis of Husserl's notion of categorial intuition, Heidegger separates the sense of the transcendental from a simple tie to subjectivity and the issue of knowledge coupled with it. ${ }^{19}$ Instead, the transcendental entails attending to the manifestation and presencing of something, the determination of its being, precisely insofar as that disclosive process can be distinguished from what is present. The process of manifestation, which is distinct from beings but nevertheless coupled with them, becomes the primary theme of phenomenology. But while his inspiration may be drawn initially from Kant, Heidegger quickly reinserts the concern for the transcendental back into the ancient Greek context prepared by Aristotle. The questioning of being from out of this context shows that the transcendental resides in revealing what makes beings be and hence in an attentiveness to that which first permits this disclosure and coordinates it with our understanding.

In this manner, ontology subordinates a concern for defining the constitution of beings even on the most universal plane, seeking a higher level of universality which brings into question the arc or horizon for any manifestness, i.e., the possibility of understanding being. In a unique manner, Heidegger succeeds in interweaving Aristotle and Kant together, preserving a perennial concern for the essential constitution of beings and transforming the cognitive emphasis on how beings can appear in relation to the conditions determining our own existence.

Heidegger's strange pairing of Kant and Aristotle comes to light in a passage from Being and Time, which later will form the heart of his radical reinterpretation of the first Critique: "If what the term 'idealism' says, amounts to the understanding that being can never be explained by entities but is already that which is 'transcendental' for every entity, then idealism affords

${ }^{18} \mathrm{Cf}$. Heidegger's discussion of phänomenologischer Kritik in GA 56/57: 125-126.

19 Heidegger, Prolegomena zur Geschichle des Zeitbegriffs, GA 20: 102; History of the Concept of Time, tr. Theodore Kisiel (Bloomington: Indiana University Press, 1984), 174. 
the only correct possibility for a philosophical problematic. If so, Aristotle was no less an idealist than Kant." Heidegger's defense of idealism as a downplaying of the subjectivistic bias often attributed to transcendental philosophy. In an innocuous fashion, Heidegger sets the stage for defining the Kantian view of truth, as set forth in his celebrated Copernican Revolution. Rather than seeing that dramatic shift as marking an attempt to seek a new ground for the appearance of things in the constitution of subjectivity, Heidegger construes the Copernican Revolution as accenting the priority of our understanding of being in governing our comportment toward beings. "Apparentness of beings (ontic truth) revolves around the unveiledness of the constitution of the being of beings (ontological truth); at no time, however, can ontic knowledge itself conform 'to' the objects because, without the ontological, it cannot even have a possible 'to what'."

Heidegger wants to consider the dynamics in the emergence of beings, yet in a way which gives attention to how that self-showing can provoke a question in us and be disclosed to our understanding. As suggested in his formulation of phenomenology, the concern for what shows itself in the most direct way possible also entails a reciprocal regard for the "letting be seen," the logos or the discursive character of that process. ${ }^{22}$ Written into ontological inquiry is a latent concern for the pattern of articulation, the matrix of intelligibility, by which being can enter the forefront of Dasein's understanding. While related to a disclosive process, the mode of discursivity is also a key ingredient of it. From Heidegger's perspective, the primary difficulty throughout the history of philosophy lies in the fact that discourse becomes separated from the disclosive process, thereby leading to the truncation of discourse in the guise of the assertion. By the same token, truth is no longer to be found within the movement of unconcealment (aletheia), but instead is displaced into the narrow confines of judgment or assertion."s

The concern for the original locus of truth then becomes the leading edge in Heidegger's earlier examination of the problem of logic in his 1926 lectures. The issue becomes particularly complex, however, insofar as the very thrust of his phenomenology lies in showing how being rises forth into intelligibility, or becomes available to discourse, beyond the narrow confines of the proposition.

\footnotetext{
${ }^{20}$ GA 2: 275; tr. 251 .

"GA 3: 13-14; tr. 8-9.

"GA $21: 919$.

2s It is important to keep in mind that Heidegger studied the structure of predication from 1912 up through and beyond his dissertation on Duns Scotus in 1926. See Heidegger's allusion to Emil Lask, to whom he looked to coordinate his early investigation into logic with the problem of the meaning-giving event of factical experience, in the Vorwort of Die Kategorien und Bedeutungslehre des Duns Scotus, GA 1: 191 .
} 
How this can occur remains difficult to see; for the very concern for the "meaning" of being suggests a way of "letting it be seen," of indicating the parameters of interpretation with the locution "as" or letting what shows itself be seen "as something." As Heidegger begins to recognize both in the Logik and in Being and Time, it is necessary to distinguish between the "as" of assertion and the "hermeneutical as." 24 Ultimately, he traces the concrete, factual origin of that difference to the development of Dasein's understanding and to its situatedness in the world. According to Heidegger, Kant, by appealing to human finitude, brings knowledge into a broader spectrum so as to rediscover its origin within the broader compass of Dasein's preliminary understanding of being (des vorgängigen Seinsuerständnis). In this way, Heidegger can appeal to the projective structure of understanding to illuminate the dynamism otherwise hidden within the occurrence of synthetic a priori knowledge.

With his Copernican Revolution, however, Kant captured the definitive characteristics of our comportment toward beings without the capacity to explore its factical occurrence in human existence. He thereby remained unable to make the correlation that Heidegger does between the anticipatory character of the a priori and and the projective structure of understanding (Verstehen) as a "determination of ex-istence." ${ }^{5}$ Due to his confinement to any ontology of the present-at-hand, "Kant did not yet see the essence and the task of a pure phenomenological interpretation of Dasein in the sense of a fundamental ontological explication of its basic structure." $\$ 6$

The key move that defines Heidegger's retrieval of transcendental philosophy, then, lies in recasting the problem of synthetic a priori knowledge as one of transcendence. But the significance of this move as implemented in the Kant book does not become explicit until we appreciate the earlier development whereby the phenomenological analysis of human existence allows for a broader recovery of understanding. Only then can Heidegger seek, in the common concern for human finitude that he shares with Kant, the prospect of discovering in time the horizon for understanding being. The temporal formation of this horizon entails transcendence. But now transcendence is no longer to be taken as a move beyond the confined sphere of subjectivity to something exterior. Rather, transcendence entails the trajectory of Dasein's entrance into the "there," as being-in-the-world. Only by exploring this more fundamental form of transcendence can Heidegger purify the "transcendental" of its contamination with a subject-object split in the Kantian sense and thereby, as seen earlier, conceive of it ontologically as including the questioning of being found

24 GA 2: 210 ; tr. 201.

23 GA 24: 389 ; tr. 275 .

-6A $25: 318$. 
in a thinker like Aristotle. By showing how Kant's treatment of synthetic a priori knowledge can be purged of its ambiguous tie to the "transcendental" defined narrowly, Heidegger can employ the Copernican Revolution as the key to addressing the possibility of understanding being.

We thereby open up a space of questioning by which to draw upon what we already understand about ourselves and uphold a broader arc for determining meaning, a space of interpretation, that allows something to be determined as something beyond the narrow fixity of the assertion. In terms of the larger inquiry into the meaning of being, the status of the "as" becomes relevant in asking how to delineate the relation between being and what fosters its disclosure, namely, time. The whole question of "being and time" is an investigation into the connective "and" linking them together, and into the formation of the concept unifying the manifold senses of being; in rising into intelligibility being can be grasped "as ...," i.e., as temporality, as emerging, coming into presence, as the dynamic advent of physis. The whole thrust of reexamining the centrality of logic, of which an inquiry into the character of the "transcendental" provides the focus, lies in marking the ascent to the apex where the "as" or the occurrence of logos unlocks for understanding, in its ecstatic dimension, the hidden affinity between being and time.

Put more in Heidegger's vocabulary, to determine the meaning of being entails isolating time as that "upon which" the projective understanding of the former can unfold. Why should this formulation of the problem then translate into a reexamination of Kant's rendering of the possibility of human experience which is outlined in his "transcendental logic"? The answer lies in the fact, as Heidegger says in the second introduction to Being and Time, that "the first and only person who has gone any stretch of the way towards investigating the dimension of Temporality or has even let himself be drawn hither by the coercion of the phenomena themselves is Kant." 27 Kant's transcendental logic becomes central by undertaking an investigation into the traditional way of distinguishing the various senses of being, e.g., via categories, only to relocate the source of their determination from reason to their temporal origin at a prereflective, prepredicative level of experience. His doctrine of schematism, on which Heidegger bases the bulk of his retrieval of transcendental philosophy, provides the novel orientation from which to rediscover the roots of logic within the larger inquiry into being.

Heidegger's reexamination of schematism, then, will be tantamount to outlining the contours of ecstatic temporality. In this way his repetition of transcendental philosophy enters the open expanse within which the "hermeneutical as" can evoke the determinateness of being and thereby satisfy a more original

7) GA 2: 31 ; tr. 45 . 
requirement for uncovering what traditionally has been intimated by the word 'being' grasped as permanent presence (ousia). In this respect, the "as" suspends the attention directed toward being in view of what yields the unique avenue for its disclosure, i.e., it establishes within discourse itself the import of the connective "and" through which being's own linkage to its condition for unconcealment, that is, time, can unfold simultaneously. The "hermeneutical as" of Being and Time comes to fruition in allowing the force of the "and" to hold sway in discourse before the inevitable identification of two different terms, being in relation to time.

In reexamining the discursivity inherent in the disclosure of being, we are naturally led to address the relevance of logic. Only recently has it become evident how central the issue of logic is for Heidegger, and from our vantage point, how his exchange with Kant must inevitably traverse this traditional territory. ${ }^{88}$ Let us consider more specifically the steps Heidegger takes to prepare for his radical reinterpretation of transcendental philosophy, and the tactics he employs (more or less presupposed in the Kant book) for removing the barriers between his own thought and Kant's.

\section{THE PREPREDICATIVE ROOTS OF THOUGHT}

However the landscape may appear from the vantage point of Kant and the Problem of Metaphysics, Heidegger must traverse a longer path in balancing his own preobjective vision of understanding (Verstehen) with Kant's more objectively oriented version of the same, namely, Verstand-the employment of its pure concepts-in order to arrive at the problem of temporality underlying them both. .9 The need to trace this development becomes particularly important in light of a criticism which Cassirer advanced against Heidegger, first in the seminar at Davos in $19^{29^{30}}$ and subsequently in his review of the Kant book in 1930.31 Cassirer questioned Heidegger's apparently abrupt translation of Kant's analyses of synthetic a priori knowledge into the ontological issue of transcendence, without first exploring what is unique about his proposal of a transcendental logic. In retrospect Cassirer's criticism, along with

${ }^{88}$ Cf. van Buren, "The Young Heidegger and Phenomenology," $260 f f$.

29 For an interesting discussion of how Heidegger distinguishes Verstehen from Verstand, see John Sallis, Echoes: Afler Heidegger (Bloomington: Indiana University Press, 1990), 147-52. Sallis suggests that not only is it necessary to "sacrifice" the rationalistic focus of Verstand, but even the more concrete employment of Verstehen must undergo development in order to be recovered through its affinity with the disclosure of being itself $(144-45)$.

so GA 3: 274-96; tr. 171-85. See my review of Taft's translation of the Kant book in Interpretation: A Journal of Political Philosophy 19 (1991): $111-14$.

s' Ernst Cassirer, "Remarks on Martin Heidegger's Interpretation," in Kant: Disputed Questions; ed. Moltke S. Gram (Chicago: Quadrangle Books, Inc., 1967), 150. 
Makkreel's more recently, suggests the need to reconsider Heidegger's starting point for his reinterpretation of Kant and to identify the importance of logic in marking the differences between these two thinkers.

Indeed, we state the difference between Heidegger and Kant too simply by emphasizing the latter's epistemic concerns. We have seen that Heidegger's primary aim is to uncover temporality as the unifying dimension in the manifold senses of being, thereby restoring to it its dynamic character as selfemerging presence (physis). By contrast, with his interest in determining the being of beings within the framework of natural science, Kant adopts a more truncated vision of beings whose appearance is confined to externally related objects present-at-hand (die Natur). Heidegger's aim is not simply to explore the underpinnings of knowledge so as to divert Kant's entire problematic from its enclosure within this restricted horizon. By showing that the categories can only address what the object can reveal to us through its appearance, Heidegger traces the origin of the categories to the prepredicative occurrence of meaning. In this way, the employment of the categories and the synthesis which they define contribute to the understanding of being and qualify them as "ontological predicates." 32

In his famous manner, Kant raises the question "How are synthetic a priori judgments possible?" He assumes that the understanding of being entailed in any cognitive comportment toward beings must be articulated in the form of a judgment or proposition, which becomes the "bearer" of truth. Yet, seen from the vantage point of Greek thought, the concern for judgment as a way of linking subject and predicate entails a prior affinity with the logos as a way of "binding" (Verbindung) or as a place of "gathering together."3s The prospect of returning to the concealed origin of Greek thought becomes even more significant given the fact that the entire emphasis of Kant's problem lies in considering the adjacent cognitive relation to the object which governs the linkage of subject and predicate. In cognition, it is a synthesis which introduces the dimension of "truth" into the proposition.

The need for such a synthesis-which for Kant entails the explicit application of the discursive side of a judgment, of the unity specified by the category, to the other, perceptual side, as given through intuition-reinforces the dependence that judgment has upon the Greek sense of logos as a gathering together. As Heidegger delineates in the Phänomenologische Interpretation von Kants Kritik der reinen Vernunft34 and in a more celebrated way later in What Is a

39 GA 3: $55 ;$ tr. 37 .

33 GA $21: 325$.

34 Heidegger, Phänomenologische Interpretation von Kants Kritik der reinen Vernunft, GA 25: 298$300,3^{2} 7 f f$. 
Thing? 35 the key to a synthetic judgment lies in the fact that the linkage of subject and predicate requires a detour to the "place" of the object; that is, only insofar as knowledge reaches out or extends toward what is "other," or altogether different, can the connection between subject and predicate which "adds something new" be successfully made. In order for a (synthetic) judgment to fulfill the conditions of truth, it must presuppose a more basic level of manifestness. For Heidegger, such a disclosure first becomes explicit in the act of transcendence.

Due to his linking Kant and Aristotle, Heidegger's aim to redefine the "transcendental" entails more than appealing to an adjacent discourse purged of all epistemic references so as to translate Kantian motifs into corresponding existential-hermeneutic ones. A more original movement is required in order that we may transpose the key concerns of Kant's thought, e.g., time and finitude, into the context opened up by his own analysis of being-in-the-world. The direction Heidegger follows first becomes evident in his strategy for recasting Kant's famous "deduction" of the categories. Kant had envisioned the task of "deducing" the categories as involving a justification of their applicability to objects (in a juridical sense). ${ }^{36}$ Yet in the lectures comprising the Logik, Heidegger had already diverged from the more commonplace rendering of Kant's concern. Heidegger rediscovers the categories as first comprising an understanding of being and then only secondarily as denoting definitive features of beings and of the objectivity determining our knowledge of them.37

Perhaps in the figure of Aristotle, to whom Kant looked to derive the pure concepts of the understanding from the table of judgments, we can find an "intermediary" position..$^{8}$ Going back to Aristotle, the categories traditionally have assumed the role of distinguishing the constitution of beings (seiendes als seiendes), and thereby have served as "ontological predicates." 39 "These concepts are the determination of the constitution of the being of beings, and are the theme of ontology." $4^{\circ}$ Yet, the entire thrust of modern philosophy beginning with Descartes, of which Kant is an heir, has been to suspend the explicitly ontological concern in favor of a reciprocal inquiry into the knowing subject. Or at least the ontological question becomes interwoven more deeply with a concern for

Is Heidegger, Die Frage nach der Ding, GA 41: 163-68; What Is a Thing? tr. W. B. Barton and Vera Deutsch (Henry Regnery Company, 1967), 161-65. Also see Heidegger's final essay on transcendental philosophy (1961), "Kants' These über des Seins," in Wegmarken, GA 9: 45 off.

${ }^{6}$ Kant, Critique of Pure Reason, tr. Norman Kemp Smith (New York: St. Martin's Press, 1965), A 84/B 117.

37 GA 21: 375ff.

${ }^{8} \mathrm{GA} 41$ : $43-48$; tr. 44-49.

39 GA $25: 295$.

0 GA 25: 295 . 
securing a transparent foundation for truth which resides in a reflective awareness of the subject to itself.

According to Heidegger, there is a regard for "deducing" and "legitimizing" the use of the categories because that task involves questioning the reliance of their predicative employment upon an equal partnership formed with the opposite stem of knowledge, namely, the receptivity of intuition. The need to trace this retreat to an intuitive level provides Heidegger with the clue to correlate the a priori conditions of experience with the prereflective "openness" essential to his own version of truth.41 The categories can assume their commanding role in designating the constitution of beings only because, in accord with the conditions set down by intuition, these predicates help to chart "in advance" the very avenue of accessibility to those beings for a finite knower. "4 The issue of the "deduction," then, is really a way of asking how the employment of the categories as presupposing logos can be brought in concert with a reciprocal concern for the manifestness of beings.

Since Kant initially determined this manifestness or pathway of accessibility to beings via the conditions of receptivity, the deduction of the categories amounts to showing how the unity specified through them can simultaneously assemble the otherwise diffuse manifold of sense given in intuition. Only through this assembling can the sense manifold be referred to the standard of orderliness and universality that constitutes a "concept of an object." 43 According to Heidegger, the categories acquire their content and their power to refer to an object precisely insofar as they call us back to and help to evoke the prepredicative form of manifestness, an advance orientation to what can appear, which guides the knowing act. By assembling the manifold of sense as a pure synthesis, the categories then direct knowledge from a prior openness solicited in advance which anticipates the form of objectivity itself.

Thus, Heidegger takes the first step toward retracting the barrier separating his own thought from Kant's; for Heidegger shows how the attempt to resolve the enigma of synthetic a priori knowledge raises concerns about the provisional conditions governing our relations to things which cannot be resolved within the ontology of the present-at-hand that Kant inherited. The a priori conditions of knowledge which Kant delineates are not then removed from experience as some static, eternal structures, but instead originate from the disclosive process of human existence which defines our factical comportment toward beings.14 Accordingly, the determination of an a priori synthesis

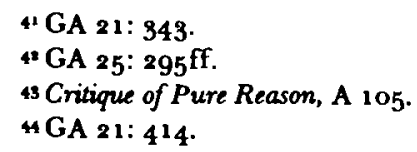


and the transcendental unity of apperception in which it is anchored do not exhibit an atemporal character; they instead display a hidden affinity with the temporal enactment of human existence.45

It becomes crucial for Heidegger to form a link between his own view of time and Kant's, insofar as temporality makes possible the primary structure of understanding, namely, projection. Insofar as through his Copernican Revolution Kant was able to discover the inner possibility of an object in antecedent conditions of human finitude, Heidegger believes that this innovation is an attempt to seek the root of any comportment toward beings in a prior understanding of being. What proves decisive from Heidegger's perspective, however, is the locution that Kant innocuously adopts to make explicit his new orientation to the problem of knowledge opened up by the Copernican Revolution. Specifically, the concern for the possibility of experience, of how the synthetic unity of the manifold makes possible any relation to an object, harks back to the projective development of understanding which is originally infused with possibilities. $4^{6}$ Residing within this projective structure lies the deeper sense of the a priori, as enunciated in the "prefix" of what precedes and comes before. By marking this latent concern for possibility, Heidegger shows that there is a connection between the occurrence of the a priori synthesis in pure understanding (Verstand) and the fore-structure of understanding (Verstehen) which governs all of Dasein's comportment toward beings.

According to Heidegger, the dynamic component of synthetic a priori knowledge takes the form of "anticipation" (Antizipation).17 "The possibility of such an anticipation of the determination of the object for all experience, the sense and the direction of such anticipation is the basic problem of transcendental logic." ${ }^{8}$ With this statement Heidegger shows that even though it is the temporality governing the preunderstanding of being which remains the primary concern, a transformation of logic is required to arrive at this ontological problematic. The key to this development lies in discovering how for Kant the need to amplify the issue of temporal finitude entails a reciprocal change in what for him, even under the auspices of the Copernican Revolution, had marked the locus of truth.

Put simply, judgment can no longer provide that focus; indeed, the root of judgment must be located in proximity with the logos as concretely embodied in those dimensions of human existence which comprise our being-in-the-

45 GA 21: 400ff.

16 GA 2: 192-93; tr. 184 .

47 GA 25: 195 .

4. GA 25: 195 . 
world, as displayed most prominently in accord with the projective structure of understanding. 49 In this way the principles describing our finite knowing capacity must "have the character of hermeneutic indication." ${ }_{50}$ Thus the "asstructure" of judgment proves to be an offshoot of the "hermeneutical as," in such a way as to exhibit the circularity inherent in understanding. ${ }^{51}$ "The saying (Logos) of that representation-is not intuition, but a determinate, articulated representation in the way of letting something be seen as something." 52 As Heidegger establishes, the components of disclosedness, understanding, disposition, and discourse facilitate any predicative comprehension of beings. "Interpretation is the mode of enactment [for enacting] the being of discoveredness. Interpretation is the basic form of all knowing." 53 Insofar as it is an act of interpretation which makes available the possibilities latent in understanding, interpretation constitutes a more primordial root for judgment.

Herein lies the chief insight, the transposition in focus, which enables Heidegger to recast the a priori synthesis as the temporal problem of imagination and thereby to reconcile his own fundamental ontology with Kant's transcendental philosophy. 54 Specifically, in view of its prepredicative dimension or its hidden affinity with the fore-structure of understanding, judgment (Utteilskraft) must admit a transformation of its own; that is, to judge is to determine the scope of meaning so as to delineate the intelligibility of what is apprehended. When anchored in its existential roots, judgment becomes a variety of "interpretation." Thus, through a reexamination of the power of judgment, Heidegger not only relocates the origin of truth in terms of disclosedness, but he also reinforces his attempt to establish interpretation as the chief guardian of "meaning." Existentially conceived, the act of judging puts into play the very same dynamics which are integral to interpretation. Thus, one of Heidegger's foremost students, Hannah Arendt, makes this remark upon accentuating the role of judgment in Critical philosophy: "In Kant judg-

$49 \mathrm{Cf}$. Stephen H. Watson, "Heidegger, Rationality, and the Critique of Judgment," Review of Metaphysics 41 (March 1988): 490-91.

50 GA $21: 410$.

${ }^{31} \mathrm{GA} 21: 474-75$. For Heidegger's later analysis of the circularity of the principles of understanding, see $\mathrm{GA}_{41}$ : $24^{2-46}$; tr. 242-44.

32 GA $21: 172$.

33 GA 20: 369 ; tr. 260 .

34 It is important to recognize that in emphasizing the mediating function of imagination, Heidegger has, in terms of the correlative place that judgment occupies for Kant in relation to reason and understanding, assigned a more primordial place to the act of judging. However, Heidegger neglects to make the implications of this development clear by not carrying out as fully as possible an analysis of the Critique of Judgment. Cf. Makkreel's Imagination and Interprelation in Kanl, 20-25, 15 off. 
ment emerges as 'a peculiar talent which can be practiced only and cannot be taught', much like any interpretive stategy." 55 The broader rendering of judgment beyond that of cognition, as becomes explicit for the first time in the third Critique, $5^{6}$ emerges as an important area of study which is not in the least exhausted by Heidegger's analyses. 57

Two results that are essential to retrieving transcendental philosophy arise from our discussion. First, Heidegger shows how it is possible to transplant an apparently epistemic question as to the formation of synthetic judgments onto an enriched ontological soil. This prepares the way for his radical reinterpretation of the Copernican Revolution and for the "violent" recasting of the basic Kantian motifs in Kant and the Problem of Metaphysics. Second, he shows how Kant's reconstruction of the terrain of traditional logic via the development of a "transcendental logic" presupposes an orientation to a prephilosophical, prescientific level of intelligibility. Insofar as this transcendental logic delineates the rudimentary concepts of the understanding (Verstand) which are the building blocks of knowledge and judgment, it must relinquish the initial architectonic plan taken from traditional logic in favor of a new matrix of meanings assembled in the fore-structure of understanding (Verstehen). Heidegger thereby seeks in Kant, despite the latter's traditionalist bent, an ally in deposing the authority of traditional logic and in rediscovering in the disclosedness of Dasein an alternative locus for truth.

Only given these preliminary steps can Heidegger proceed more radically in the Kant book to overthrow the tyranny of reason in favor of the temporalizing activity of imagination and to recast synthetic a priori knowledge as the problem of transcendence. The $19^{2} 5^{-1926}$ lectures entitled Logik: Die Frage nach der Wahrheit prepare the way for this development. They provide the key step in Heidegger's destructive retrieval of transcendental philosophy, a step which is too easily overlooked in his exchange with Cassirer. That is, in reciprocity with the transcendental unity of apperception, time "as the universal a priori form" satisfies the condition for the binding together of representations in a judgment, $5^{8}$ and thus implicitly points back to the original formation of meaning and discursivity (logos) that is intrinsic to any understanding of being. 59 In this way, the Logik shows how Kant's thinking provides a regressive

55 Hannah Arendt, Lectures on Kant's Political Philosophy, ed. Ronald Beiner (Chicago: The Chicago University Press, 1982), 4.

${ }^{6} 6$ Kant, Critique of Judgment, tr. J. H. Bernard (New York: Macmillan Publishers, Inc., 1951). We will not here discuss the importance of the distinction between reflective and determinate judgments, which Heidegger does not address in detail.

$57 \mathrm{Cf}$. Makkreel, Imagination and Interprelation in Kanl, 14 off.

${ }^{88} \mathrm{GA} 21: 334-38$.

59 GA $21: 3^{86-87}$. 
path back to temporality as the self-organizing matrix of meanings that not only unifies Dasein's being as care but also makes possible its intentional comportment toward beings. The self-affective character of time in its affinity with the "I think" prefigures the temporal unification of care. "Temporality is the ground of the possibility of the structures of care itself. Anticipation is a mode of time, and in no way does it have a presence in time. Time cannot in any way be present-at-hand, nor can it be a determinate kind of being-but instead it is the condition of the possibility for that, that there is something like being (not beings)."6o

Yet, even given the removal of dissimilarities separating his own thought from Kant's, Heidegger continues to clarify how a retrieval of transcendental philosophy provides a positive inroad into the hermeneutical situation governing his own thought. This inroad must not only mark the reciprocal implication holding between Dasein and the question of being; on the even more concrete level of facticity it must also keep in check the tendency toward forgetting which conceals that circularity and diverts questioning toward an indifferent apprehension of beings as present-at-hand. The need for philosophy to confront that forgetfulness, and to draw forth from an opposite pole what conditions the givenness of the present, defines Heidegger's task in The Basic Problems of Phenomenology. In Chapter 1 of the Basic Problems, Heidegger undertakes a reexamination of Kant's thesis about being as "position" in order to find a new point of departure for ontology.

\section{REGRESSIVE DESTRUCTION VS. DESTRUCTIVE RETRIEVAL}

In his discussion of Kant's thesis about being, Heidegger coordinates Kant's insights about the presumptuous attempts of previous thinkers to prove God's existence with a greater appreciation for the development of philosophy as a historical task. Heidegger includes in his reappraisal of transcendental philosophy a concern not only for history, but also for the way that the acquisition of a historical sense determines the course of philosophical inquiry. What Kant fails to see is that the deficiencies of rational metaphysics which he uncovers are embedded more deeply within the tradition, and that any counterproposal he makes-the schematism of the categories-proves viable only when transposed into a broader inquiry aimed at undoing the accumulated confusions of Western thought.

Put simply, Kant's insights are only as provocative as the concerns stimulating them. When in the Transcendental Dialectic Kant claims that 'being' qua existence cannot be defined as an overt property of something, he does not merely disclaim the attempt by rational metaphysics to adduce God's existence

${ }^{60}$ GA $21: 410$. 
from our concept of it (i.e., as the ens realissimum). Rather, the import of his "thesis" is that the object (Gegenstand) can exist and stand apart from our concept of it, precisely because its appearance occurs in reciprocity with the conditions of human finitude. Requisite to this appearing, as suggested in Kant's own account of schematism, is the offering of the area in which the opposition of the object can take place for a finite being. Kant's transcendental logic constitutes an advance precisely because it introduces the correlative concern for truth that is foreclosed to rational metaphysics, and thereby works against the adoption of a simplistic doctrinal stance. ${ }^{61}$

For Heidegger, Kant's critical approach proves decisive only because it can, in line with a more primordial concern for truth, mirror the even more radical kind of questioning that comprises fundamental ontology.62 But in order for ontology to reach this level it must recognize a distinction which allows being to be addressed thematically and facilitates its comprehension in a discursive way, namely, the ontological difference. "This distinction is not arbitrary; rather, it is the one by which the theme of ontology and thus of philosophy itself is first of all attained. It is a distinction which is first and foremost constitutive for ontology. We call it the ontological difference-the differentiation between being and beings."63 Heidegger does not explicitly allude to the ontological difference in Being and Time; yet it is the concern raised by it, of attaining an original point of departure for ontology, that leads him to establish its inescapability as the central topic governing his exchange with transcendental philosophy.

In retrospect, Heidegger's suggestion that the categories not only must have a temporal affinity, ${ }^{64}$ but even more radically have time as their origin, brings the deepest stem of knowledge or imagination more closely in line with Dasein's disclosedness. Though over a sixty-year span critics have identified difficulties with Heidegger's account of schematism, Heidegger refrains from simply substituting metaphysical for epistemic concerns. ${ }^{65}$ Rather, as our emphasis on the 1925-26 lectures of the Logik shows, the structure of synthetic a priori knowledge can be revealed in terms of a deeper unity that is indicated by the components of Dasein's disclosedness. This more fundamental experience of truth does not provide a new orientation for metaphysics or even establish its priority, as much as mark the point of departure from which the viability of its task can be brought into question. Thus, Heidegger captures

6. Cf. Kant's discussion of dogmatism in the first Critique, B xxxv.

6. GA 24: 23; tr. 17 .

63 GA 24: 23; tr. 17 .

G Kant, Critique of Pure Reason, A 138/ B 177 , A $139 /$ B 178 .

65 Cassirer, "Remarks on Martin Heidegger's Interpretation of Kant," 15 off. For a somewhat different perspective, see Makkreel, Imagination and Interpretation in Kant, $25 \mathrm{ff}$. 
this nuance by employing the phrase "problem of metaphysics" in the title of his 1929 work on Kant. ${ }^{66}$ Heidegger alerts us to the fact that the previously overt regard for metaphysics must now give way to questioning its inner possibility. ${ }^{67}$

For Heidegger, the key to charting this new course of inquiry lies in bringing the ontological difference into the foreground. Precisely because the arrival of a new departure for investigation is underway, it is necessary to reexamine the very character of the phenomenological method. To this end, Heidegger identifies the threefold task of phenomenology as reduction, construction, and destruction. ${ }^{68}$ Reduction involves the direction of inquiry leading away from beings back to the prior understanding of being. Construction entails the thematic unfolding of that preunderstanding in terms of the essential components of Dasein's disclosedness. And finally destruction involves removing the accumulated confusions of the tradition which stem from a neglect for the question of being and which conceal the origin of philosophy in the ontological difference. For the sake of clarification, there may be a tendency to isolate each of these moments, for example, to confine the destructive phase to Heidegger's historical exchange with Kant. But in another sense we can also witness the interplay of these moments in any interpretation. In the 1926 lectures, for instance, the redirection of Kant's thought from out of its confinement to an ontology of the present-at-hand back to an antecedent understanding being entails reduction, even though its historical import and orientation implies destruction as well. Likewise, the reassembling of the hermeneutical situation which defines Heidegger's project in Being and Timeoutlining the horizon for the projective understanding of being-involves construction. But because that development requires the historical retrieval of transcendental philosophy, we find the moments of destruction and reduction included also.

In a certain sense, Heidegger practices destruction throughout the Basic Problems (1927), insofar as he examines the four historical theses about being, beginning with the Kantian version, "being is not a real predicate." Yet, because these lectures only prefigure the retrieval of transcendental philosophy which reaches its zenith in the Kant book, the initial delineation of the Kantian thesis appears as a specific variation of what we might more generally describe as the task of destructive retrieval. Insofar as in his account of the Kantian thesis Heidegger does not initially show how transcendental philosophy provides a nascent outline for his own project of fundamental ontology, his analy-

\footnotetext{
${ }^{66}$ GA 3: xvii; tr. xix.

BA GA 235; tr. 160 .

6A 24: 28-32; tr. 21-23.
} 
ses assume more of a "regressive" character. That is, by marking the contours of what has been forgotten, Heidegger indirectly seeks the clues that refer back in questioning (Rückfrage) to a more originary point of departure that calls forth an antecedent understanding of being. In this way the Kantian thesis proves decisive; for it retroactively points to omissions which are so acute as to require a countermovement of inquiry culminating in the question of being.

Kant's thesis that being is not a real predicate occurs within the Transcendental Dialectic, which comprises the second half of transcendental logic. Heidegger's selection of the Kantian thesis may at first appear somewhat strange except insofar as we recognize his later emphasis on addressing the crisis in metaphysics, of which Kant's examination in the Critique of Pure Reason serves notice. Yet, the preliminary step we have taken in examining Heidegger's view on logic proves enlightening here. For the very thrust of Kant's criticism is to derail the misemployment of logic which governs the spurious attempt to prove the existence of God. Reason which is detached from the conditions for the manifestness of beings, and uprooted from human finitude, attributes the characteristic of existence to an ultimate ground. But this ground does not admit appearance as an object in accord with any factual conditions, and thus reason becomes caught in its overzealous pursuit of advocating pure presence, an illusion of arriving at the absolute totality of conditions. ${ }^{69}$

For Heidegger, what is the significance of Kant's exposing the spurious assumption of rational metaphysics? Kant maintains that being as existence is not an attribute analytically contained in a concept but a synthetic determination holding between a concept (in this case God) and an object. The synthetic characterization of existence means that it cannot be defined by reason alone on a model of an infinite intellect seeking perfect ontical knowledge. Instead, we must refrain from simply identifying the notion of existence with presence-athand, as if it were immediately accessible, like some ontical characteristic to be singled out by ostension. The sense attributed to being is not to be reached ostensively, but only arrived at through a prior assembling of a horizon in conformity with our finitude. Only through the establishment of something like a perceptual continuum in accord with the (pure) sensibilized conditions of space and time can we attribute existence, and, through an object's emergence within the horizon of manifestness, identify it ostensively in terms of the temporal dimension of the present (Gegenwart).

What is the upshot of Heidegger's reexamination of the Kantian thesis? We find that the attempt to circumscribe 'being' too narrowly within the purview of

69 Kant, Critique of Pure Reason, A 334/ B 392. For an insightful discussion of this problem, see John Sallis, The Gathering of Reason (Athens: Ohio University Press, 1980), 135 ff. 
presence (Anwesen) leads to its misidentification of what can be present, i.e., a being, that is, a blurring of the distinction between being and beings. As such, the crisis in (rational) metaphysics which Kant identifies as reason's attempt to outstrip possible experience arises from neglecting the horizon for understanding being, from failing to heed the ontological difference. $7^{\circ}$

In this way, we discover how Kant's thesis about being, despite its negative character, really supplies an important clue to an essential ingredient in the understanding of being, its discursivity. As Heidegger will later state in The Melaphysical Foundations of Logic (1928): "Being is different than beings, and only this difference in general, this possibility of distinction, insures an understanding of being." $"$ This insight foreshadows Kant's recognition of the emptiness of the concept of being within rational metaphysics and the difficulties surrounding its articulation. In flagging this forgetfulness, this fateful withdrawal of being, Heidegger also uncovers the alternative prospect of arriving at what fosters the understanding of being, the advent of its disclosure. $7^{*}$ The recognition of how not to address 'being' becomes relevant within a regressive movement whose aim is to reach the otherwise hidden conditions for understanding being, to question what has been excluded in the simple identification of being with presence, namely, the concern for temporality.

Seen in this light, "Kant's thesis about being" displays a curious obliqueness which conceals the role time is given in defining our understanding of being. But this obliqueness only points out the tenacity which the neglect for temporality has had in distorting ontological inquiry, and, by implication, the urgency of counteracting that neglect by executing the kind of retrieval which Heidegger proposes. Kant's thesis, then, turns out to be "about being" precisely because it diverts our attention from it, directing our view not toward being initially, but toward what was withheld from consideration conjointly with it, namely, time. The obliqueness of Kant's allusion to being becomes an invitation to follow the entire transposition in his ontological problematic, to recall that disproportion and rupture which gives attention not to being, much less only to time, but to the reciprocity between them.

With this regressive move, Heidegger anticipates the decisive concern which governs his analyses in the Kant book, namely, addressing the connective

T0 Frank Schalow, "Re-Opening the Issue of World: Heidegger and Kant," in Man and World $20\left(19^{8} 7\right): 200$.

${ }^{71}$ Heidegger, Melaphysische Anfangsgrïnde der Logik im Ausgang von Leibniz, GA 26: 193; The Metaphysical Foundations of Logic, tr. Michael Heim (Bloomington: Indiana University Press, 1984), $15^{2}$.

72 For a later attempt to think the basis of this understanding of being, see Heidegger's 1936 lectures Beitrage zur Philosophic (Vom Ereignis), GA 65: 455. For an attempt to defend Heidegger's strategy for thinking the "unthought" origin of metaphysics, cf. Steven Crowell, "Texts and Technology," Man and World 23 (October 1990): 433, 437. 
"and" that joins being with time. Through his analysis of schematism, he establishes that time is not simply an extension of the present, but includes the formation of the other ecstases, of future and past. In this way it becomes possible to offset the traditional view of being as permanent presence and question back to the formation of that horizon which first grants the possibility of understanding being. Thus, destruction and reduction blend together with construction to mark the crucial juncture where Heidegger can extend his inquiry, that is, by eliciting the "upon-which" for the projective understanding of being. For Heidegger, the temporal character of schematism ceases to be merely a variation of the temporal series involved in outlining the sequence of natural events. Instead, temporality determines the ecstatic formation of selfhood, as embodying finite transcendence, and thereby exhibits the same animating quality of historical life that Heidegger (with an eye to Dilthey) believed determined the movement of authentic questioning. As Heidegger acknowledges, Kant's thought is properly called transcendental philosophy because in the richest sense it is rooted in the problem of transcendence (temporality). 73

We will not consider any further this later development of Heidegger's appropriation of Kant's thought, the heart of his destructive retrieval of transcendental philosophy.74 From our standpoint, what becomes important are Heidegger's remarks at the end of the Basic Problems, which refer back to his observations at the beginning of Being and Time. Specifically, in contrast to the positive sciences, Heidegger states that ontology is a "Temporal science." 75 Further, he states that "all propositions of ontology are Temporal Propositions" and that these "have the character of Temporal truth, veritas temporalis." 76 The latter remarks become particularly telling in light of his suggestion in Being and Time that phenomenology is an exercise in "transcendental truth."

The preparatory stages in Heidegger's dialogue with Kant lead us to the threshold where the traditional task of metaphysics and the discourse defining it are redirected from another beginning. What does Heidegger then mean by the "problem of metaphysics" in the title of his work, a query which he will later voice in What Is a Thing? 77 Given our preceding discussion, he has in view

\footnotetext{
73 GA 24: 423; tr. 298.

$74 \mathrm{It}$ is important to keep in mind Heidegger's emphasis in the late Marburg period on bringing about a transformation within ontology itself; he refers to the development of "metontology" that redirects the inquiry into the possibility of understanding being toward the more direct relevation of beings themselves that first provokes in us the question "Why?" Cf. GA 26: 199-202; tr. 157-58. Also see John Sallis's account of how the development of metontology involves renouncing the "claim of Verstand" in favor of a disclosure that fosters the emergence of beings; Echoes: Afler Heidegger, 149.

73 GA 24: 460 ; tr. 323 .

76 GA $24: 460 ;$ tr. 323 .

$77 \mathrm{GA}_{41}$ : 127 ; tr. 125 .
} 
juxtaposing and holding in a tension the traditional issues of metaphysics, though within a discourse or discursivity that moves in an opposite direction to the conventional formulations. The bearing of this tension defines the new task reserved to phenomenology. Being and Time is not just a Kantian enterprise because it takes over similar terminology. Rather, it proves to be more originally Kantian by readapting that vocabulary and redirecting it from another attunement to the logos, which allows for a deeper preservation and appropriation of Kant's problematic. Through Kant's thought Heidegger can then adopt the logical concern of truth and judgment first raised in Husserlian phenomenology and bring them into a wider ontological orbit in accord with the question of being. As Heidegger states toward the end of the Phänomenologische Interpretation von Kants Kritik der reinen Vernunft in 1928: "When I began to study Kant's Critique of Pure Reason again a few years ago and read it, as it were, against the background of Husserl's phenomenology, it was as if the scales fell from my eyes, and Kant became for me the confirmation of the correctness of the way for which I was searching." 78

With this observation, we reach the end of our account of the initial stages of Heidegger's dialogue with Kant. What we ultimately discover is how outlining the topography for asking the question of being, of the original hermeneutical situation, includes as its intrinsic component the reissuance of ontology from a "truly" Kantian beginning. Heidegger's turn to transcendental philosophy proves to be not so much an anomaly in the development of his phenomenological task as an important step in his attempt to couch traditional logic in a more fundamental experience of truth. Accordingly, the unfolding of this Kantian beginning will always pose a special challenge and consequently present a special reward for those who wish to persevere in making it. It is one which will enable us to open up new vistas, and, even for those who wish to downplay the importance of transcendental philosophy in Heidegger's development, this beginning remains to a large extent inescapable.79

\section{Tulane University}

${ }^{78}$ GA 25: 431.

79 I wish to express my thanks to the editor for his helpful comments on my paper, as well as to the anonymous readers for their suggestions on how to strengthen my thesis. 